\title{
サブプライムローン問題と 金融市場
}

深尾光洋

\section{1. はじめに}

本稿では、まず2008年 9 月に米国で拡大した 金融危機の経緯を概観するとともに、その原因 を探る。特に、米国の大手投資銀行の資産内容 が不透明であり、破綻したリーマン・ブラザー ズの資産内容の劣化は、1990年代後半の日本 の金融危機における日本の金融機関の資産内 容と比較しても、予想外に激しいことを指摘す る。最後に、今後どのように金融監督体制を整 備すれば、こうした金融危機の再発を抑制でき るかについて考察する。

\section{2. 金融危機拡大の経緯}

サブプライム問題は、 2007 年の春から夏に かけて表面化し、2007年の夏には複数の金融 機関が大きな損失を発生させた。2007年6月に ベアー・スターンズ傘下のヘッジファンドが大 きな損失を発表した。さらに、7〜8月にドイ ツの金融機関が、また10月にはシティをはじ めとするいくつかの金融機関が損失を発表し、 アメリカの複数の金融機関のトップが責任を とって交代した。2008年3月には、アメリカで 5 番目の投資銀行であるべアー・スターンズが 事実上破綻状態に陥り、FRBが実質的な瑕疵 担保責任を提供し、中央銀行がリスクを負う形 で、JPモルガンによる救済的な買収が行われ た。これにより、アメリカで5番目より上の投
資銀行については恐らく破綻はないのだろう という、"too big to fail"のラインが見えたとい う安心感が広がり、一時的に金融市場は安定化 した。

さらに 08 年 9 月 7 日、財務省がファニーメイ とフレディマックに対する救済策を発表する。 ファニーメイとフレディマックは日本の住宅 金融公庫に当たる金融機関であり、保証を含め た 2 社の負債総額合計が 500 兆円に上る巨大な 金融機関である。日本の GDPが約500兆円、ア メリカの GDPが約 1,500 兆円であるため、ファ ニーメイとフレディマックの500兆円の負債総 額は非常に大きい。この 2 社については、政府 が実質的に無制限に資本を提供するという約 束をすることで救済した。この時点までは、政 府は市場の期待に添った動きをしていた。

しかし、08年9月 15 日になると、リーマン・ ブラザーズ（以下リーマンと略称する）がチャ プター11の適用を申請して破綻する。この直 前の週末である13日と14日には、アメリカの 金融界のトップが連銀に集まり、リーマンの救 済についての大議論が行われ、最後の最後のと ころで、ポールソン財務長官は「リーマンに対 しては政府資金を使った救済を行わない」とい う結論を出して破綻する。

リーマンは規模から見ると、ベアー・スター ンズより一つ上に位置する4位の投資銀行であ る。5位は救われたが、4位が実質上破綻した ため、その上の投資銀行は政府による救済があ 
るのかどうかについての市場の疑心暗鬼が広 がり、3位と 2 位の投資銀行であるメリルリン チ、モルガン・スタンレーの 2 社に対する信用 不安が拡大した。

リーマン・ブラザーズの経営危機とほぼ同時 に、アメリカのトップクラスの保険会社である AIGが資金繰り難に陥った。AIGは、2007年 の有力経済誌「フォーブス」で全米トップ企業 の一つにも選ばれ、一般に優良企業だと思われ ていた保険会社であったが、突然資金繰りに詰 まって米国の中央銀行である連銀に駆け込む という事態に陥った。

しかも、リーマンの場合は倒産時点まで、 $\mathrm{CP}$ (コマーシャル・ペーパー) は最上級の短 期格付け、長期格付けも、格付会社フィッチ は破綻の少し前までダブル A（破綻直前にシン グル Aに格下げ)、ムーディーズと S\&Pの格付 けもシングル A 格であった。AIGに至っては、 非常に高い格付であるダブル A 格のまま実質 上破綻状態に陥った。こうした信用度が十分高 いと思われていた金融機関が突然、実質破綻状 態になったため、金融市場は大混乱に陥った。

この後、連銀は他の主要国の中央銀行と協力 して、世界各国で活動している米銀に対するド ルの流動性の供給を開始する。さらに米財務省 は08年 9 月 19 日に 7,000 億ドル、約 70 兆円規模 の金融危機対応策を発表した。この法案は、一 度下院で否決されるなど大きな議論を呼んた が、上院で改正案を可決した後 10 月 3 日に下院

\section{PROFILE}

深尾光洋

(ふかお みつひろ)

慶應義熟大学商学部教授

専門：国際金融論、コーポレート・

ガバナンス

で可決されてょうやく成立した。

当初ポールソン財務長官は、「不良債権の買 取り枠が7,000億ドルである」と議会に説明し ていたが、この救済策がまとまると、突然、不 良債権の買取りを資本注入に読み替えて、公的 資本注入を発表した。このほか、連銀による実 質ゼロ金利政策の開始や連銀による民間企業 への資金供与などにより、ようやく落ち着きを 取り戻した。(図表1)

\section{3．金融危機深刻化の背景}

もともと、サブプライム問題は、フロリダ、 カリフォルニアあるいはネバダといった地域 の不動産価格が大幅に值下がりしたことが端 緒になっている（図表2）。しかし、不動産関 連貸出による金融機関の損失額は、サブプラ イムより広い範囲までとっても、せいぜい 1 兆 ドルと言われている。1ドル100円で換算して 100 兆円という金額は、日本の銀行部門全体が いわゆる「失われた 10 年間」に計上した不良 債権損失と同程度である。米国経済のGDPは 日本の約 3 倍であり、経済規模に対比した米国 
図表 1 米国金融危機のタイムライン

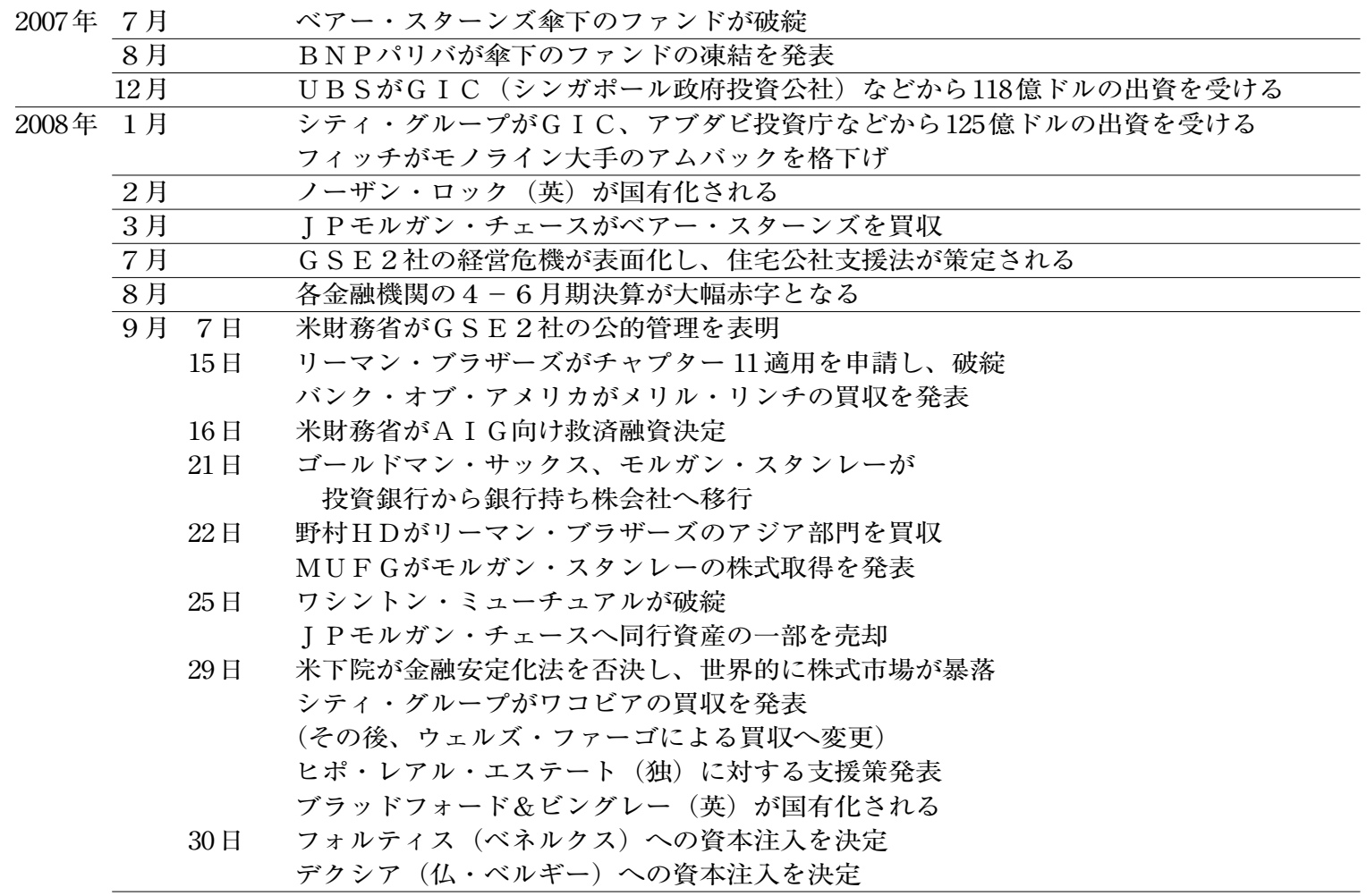

10月 3 日 米下院で修正後の金融安定化法案を可決

7 日 アイスランドが非常事態宣言を発し、全ての民間銀行を国有化

8 日 A I Gに対して最大 378 億ドルの追加支援措置を発表

10 力国・地域の中央銀行が同時利下げを実施

10 日 G 7 財務相・中央銀行総裁会議を開催し、「行動計画」を公表

13 日 英政府が主要 3 行に 370 億ポンドの資本注入実施を表明

14 日 米国政府が最大 2500 億ドル（大手行 9 行に 1200 億ドル）の公的資本注入を発表

16 日 スイス政府がU B S に対する 60 億スイスフランの資本注入を発表

29 日 I M F と E Uがハンガリーに対する251億ドルの救済策に合意

11月 3 日 韓国政府が14兆ウォン規模の経済対策を発表

5 日 独政府が500億ユーロ規模の経済対策を発表

9 日 中国政府が 4 兆元規模の経済対策を発表

15 日主要 20 力国・地域（G 20）首脳会合を開催し、「首脳宣言」を公表

23 日米国政府がシティ・グループに対する 3260 億ドルの支援策発表

24 日 英政府が 200 億ポンド規模の経済対策を発表

26日 欧州委員会（E C）が2000億ユーロ規模の経済対策を発表

12月 4 日 仏政府が 260 億ユーロ規模の経済対策を発表

12 日日本で「改正金融機能強化法」が可決される

16日ＦＲＢが政策金利を引き下げ「実質ゼロ金利政策」を採用

19 日 米政府が $\mathrm{GM}$ とクライスラーに対する 174 億ドルの支援を発表

2009年 1 月 15 日 米議会が問題資産買取プログラムの残額 3500 億ドルの利用を承認

19日 英政府が追加銀行救済策を発表

2月 10 日 米財務長官が新金融安定化策を発表

17 日米国で7870億ドル規模の経済対策が成立

18日＼cjkstart米政府が住宅市場支援策を発表

日本経済研究センター金融研究班報告書 20 号、図表1-1、2009年3月 


\section{図表2 ケースシラー住宅価格指数}

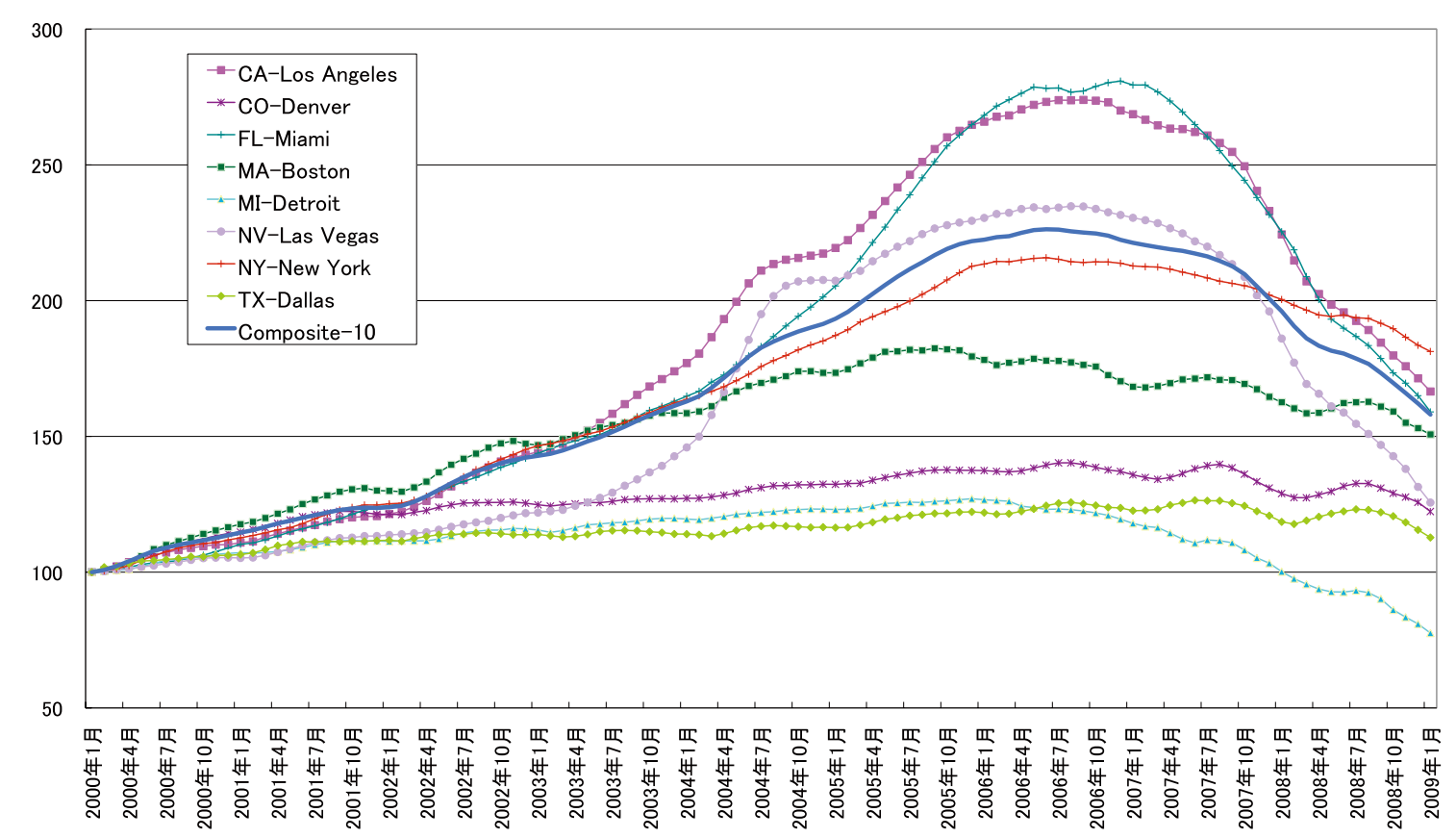

注：S\&Pのウエブサイトのデータから筆者作成。

金融部門の損失は、日本の 3 分の 1 程度である。 しかも、100兆円の損失のうちの約 40 兆円程度 はヨーロッパの金融機関が負担しているので、 アメリカの金融機関が負担したサブプライム ローン関連損失は50兆円ほどであり、経済規 模に対比すると、日本の金融機関よりもかなり 小さな損失であったといえる。

このため米国政府当局者も2008年夏までは、 対応を誤らなければ、日本のような大きな金融 危機にはならない状況だと判断していたと見 られる。しかし実際には、世界規模の金融危機 が発生した。この背景には、次のような要因が あったと考えられる。

\section{（1）非常に高い実質負債・資本比率}

SECは2004年に大手投資銀行 5 社に対する 資本規制を弱めている。当時までの資本規制で は、総負債・資本比率（レバレッジ倍率）は 10〜15倍程度が上限であったと言われている。 しかしこの規制緩和により、30〜40倍のレバ レッジ倍率が容認されるようになった。

\section{（2）デリバティブ取引、証券化商品取引の拡大}

2000 年台に入って、デリバティブや証券化 商品を使った高レバレッジ取引が拡大した。特 に、CDS（クレジット・デフォルト・スワップ） が非常に拡大したこと、あるいは、SPC、SPV (特別目的会社等)を使ったファイナンスが拡 
大したことが重要である。SPC、SPVについて は、リスクが完全に切り離せていない、本来 連結決算から外していけないと思われるもの を多数外していたように見える。例えば、SPV のスポンサーとなった金融機関が当該 SPV と の間で「特別目的会社が流動性不足に陥ったと きに資金を供給する」という契約を結んでいる 場合、本来はそのSPVを連結すべきだったと 思われるが、それをしていなかった。

\section{（3）プライム・ブローカレッジ}

さらに投資銀行による、ヘッジファンドに対 するプライム・ブローカレッジの提供にも大き な問題があった。例えばリーマン・ブラザーズ はヘッジファンドとプライム・プローカレッジ 契約を結んでいた。この契約では、投資銀行は さまざまな有価証券やデリバティブの売買の 仲介を、安い手数料でそれを行う。しかしその 代償として、ヘッジファンドが預け入れた資産 を投資銀行が自らの担保としてもう一回使っ てよいという契約を結んでいた。具体的には、 まず、ヘッジファンドがリーマンにプライム・ ブローカーを依頼する。ヘッジファンドは自分 の保有する金融資産をリーマンに預けておき、 それを担保にしてリーマン経由で金融資産の 売買や資金·有価証券の貸借取引を行う。但し、 リーマンは、この預かった顧客の担保資産を自 分の資金運用の担保に使うことができる。この ようにもともとの金融資産に対して二重のレ バレッジをかけていた。

\section{3. 政府による金融危機対応の 失敗}

米国政府はサブプライム問題が深刻化する 中で、重大な失敗をしたと考えられる。その一 つは、米財務省とFRBが投資銀行としては格 下のベアー・スターンズを救済した後に、その 上のリーマンを破綻させたことである。これは、 市場参加者の期待とは大きく異なる政府の対 応であったため、以下のような経緯を経て市場 の混乱を拡大した。

第一に、リーマンは、金融派生商品（デリバ ティブ）取引市場における、大きな取引主体で あったため、リーマンの取引の相手方は先物、 オプションなどの巨額の金融派生商品取引を 非常に短期間で清算する必要に迫られ、大きな 混乱を招いた。金融派生商品の本質は、金利、 為替相場、株価、信用リスク等の変化に対する 賭を行うものであり、必ず勝ちサイドと負けサ イドが発生する。リーマンに対して勝っている 取引先は、リーマンの破綻に伴って賭の勝ち金 の大部分を失い、大きな損失を被った。さらに リーマンの取引の相手方は、金融派生商品の精 算に伴い、リーマンとの取引によって構築して いた投資ポジションやリスクヘッジを再構築 する必要に迫られ、大きなコス卜負担を迫られ た。すなわち、金利、為替相場、株価、信用リ スク等の変化に伴って、金融派生商品の価值が 変化することを見込んで作っていた投資戦略 やリスクを削減する取引が、リーマンの突然の 
破綻に伴って維持できなくなり、再び別の金融 機関と契約を結び直す必要が生じた。これには ある程度の時間が必要であり、しかもリーマンの 破綻に伴って金利、為替相場などが大きく変化 したために、相当の損失を被る顧客が発生した。

第二に、リーマンの債務の評価額は、その 破綻の後、元本額面のわずか $9 \%$ にまで低下し た。リーマンの短期格付けは破綻直前まで最上 級であったため、アメリカのMMF（優良な短 期金融資産で運用する投資信託で、証券会社の 預かり口座）の一部は、運用のためにリーマン の社債を組み込んでいた。しかしリーマンの破 綻に伴い、これらのファンドは元本割れとなっ た。MMFは、金融機関や資産家層が短期資金 運用のために保有する、極めて流動性の高い投 資信託であり、実質的に当座預金同様に使われ てきていた。これが元本割れを起こしたため、 MMFに対する取り付け的な資金引き出しが発 生した。MMFは米国企業が短期資金調達のた めに多用するCP（コマーシャル・ペーパーで 実質的には短期社債）の重要な買い手であった が、取り付けを見てCPの買い付けをストップ したため、一般企業の資金繰りを急激に悪化さ せた。

第三に、リーマンの負債の極めて低い評価額 は、金融機関の財務内容の開示に対する信頼を 喪失させた。この元本の $9 \%$ という数字は、後 で述べるCDS（クレジット・デフォルト・スワッ プ）の決済のために、リーマン破綻の 1 ケ月ほ ど後に行われたリーマン債務のオークション
での価格であるが、これは非常に低い水準であ る。日本の破綻金融機関の負債評価額を預金保 険機構の資金援助額などから計算すると、大阪 の木津信組の破綻事例が最悪のケースであり、 清算価值は元本の $23 \%$ 程度であった。また大 手金融機関の日本長期信用銀行で $88 \%$ 、日本 債券信用銀行で $71 \%$ 、山一證券で $97 \%$ と、リー マンのケースよりもはるかに高い清算価值を 維持していたといえる。このように、破綻前の 資産規模に比較して極端に低い清算価値は、金 融機関が開示する財務諸表に対する不信感を 強め、金融市場において金融機関がお互いにそ の健全性を信頼できなくなる状況を生み出し た。

第四に、リーマンとプライム・ブローカレッ ジ取引を行っていたヘッジファンドは、リーマ ンに預けてあった金融資産を引き出すことが 不可能になり、大きな損失をこうむった。一 部のファンドは巨額の損失をこうむって経営 が悪化した。またリーマン同様にプライム・ブ ローカレッジを行っていたモルガン・スタン レーなどの他の投資銀行についても、リーマン の破綻に伴う信用不安が発生し、預かり資産が 流出した。これは投資銀行の預かり資産に対す る一種の取り付けであった。

\section{AIGの破綻とCDSリスクの 顕現化}

このリーマンの破綻に伴う信用不安の拡大 
で、リーマンとほぼ同時に資金繰り困難に陥つ たのがAIGである。AIGは米国最大級の保険 会社であり、2007年には米国の経済誌である フォーブズ・マガジンの全米トップ企業 10 社 に選ばれるなど、一般に優良企業と見なされ ていた。しかし、AIGは保険業務に加えて、ロ ンドンにあったAIGの金融派生商品取引部門 (AIG Financial Products) がリスクの大きな金 融派生商品の一種であるCDS（Credit Default Swap）を大量に取引していた。

CDSは債務保証に近い機能を持つ金融派生 商品である。かりに $\mathrm{A}$ 銀行が $\mathrm{B}$ 社の社債を持っ ている場合を考える。B社が破綻すると A 銀行 は大きな損失を被る。この倒産リスクをヘッジ する機能を果たすのがCDSである。A 銀行は
C投資銀行から B 社が破綻した場合に、その損 失額を補填してもらうCDSを購入できる。A 銀行は保証料に相当する金額を C投資銀行に支 払い、その見返りにC投資銀行はB社が万一破 綻して債務不履行に陥った場合に、損失相当額 を $\mathrm{A}$ 銀行に支払う。これにより、 $\mathrm{A}$ 銀行はC投 資銀行から B 社の破綻リスクに関するプロテク ションを買ったといえる。

しかしCDSは単なる債務保証ではない。A 銀行はB 社の社債を持っていなくても、B社の 破綻リスクのプロテクションをC投資銀行から 購入することができる。この場合には、A 銀行 はB社が破綻すると利益が出るタイプの賭を C 投資銀行と行っていることに相当する。また投 資銀行の顧客である、A 銀行はB 社のプロテク

\section{図表3}

CDS想定元本（兆ドル）

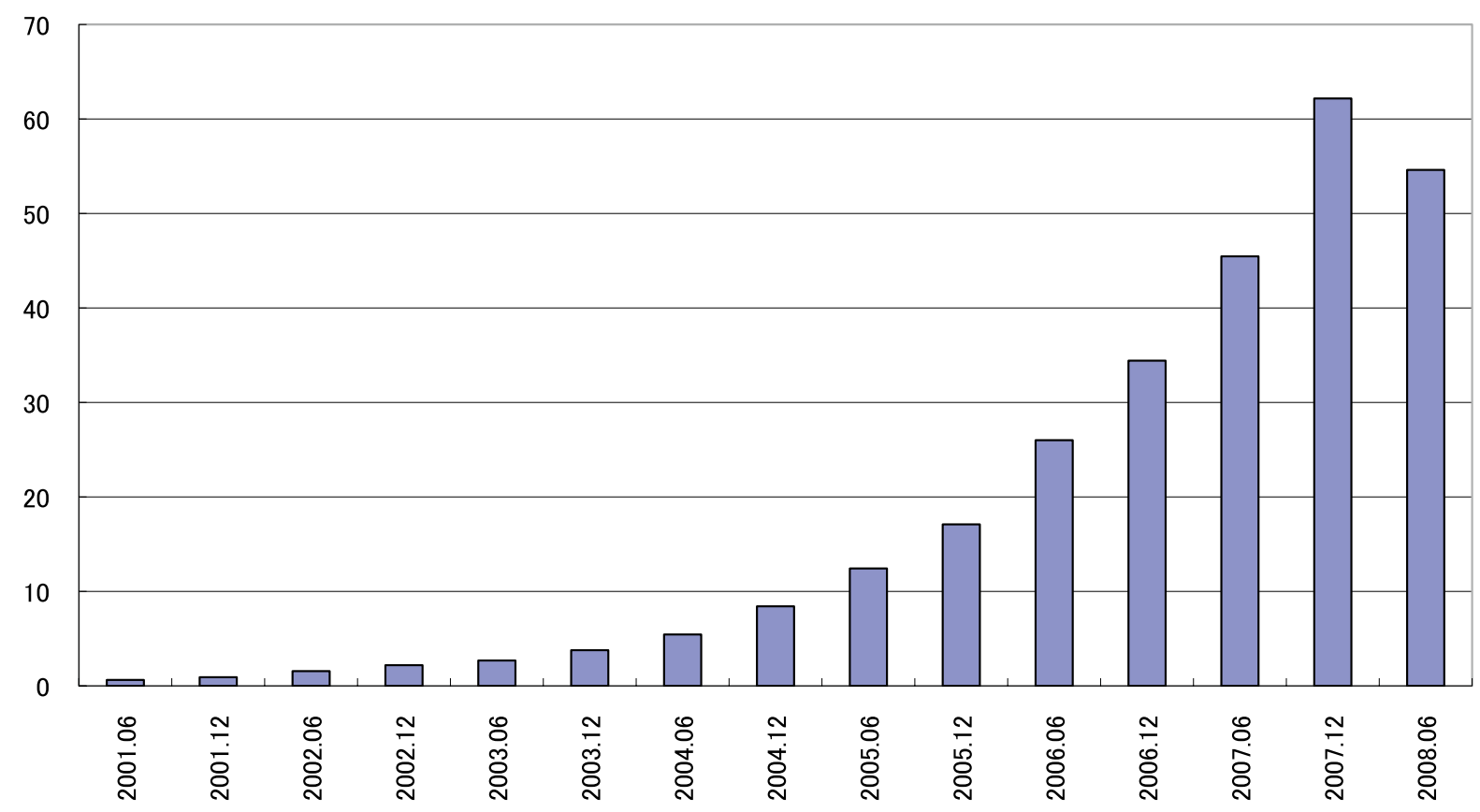


ションを買うだけでなく、B社のプロテクショ ンを売ることも可能である。すなわち、A 銀行 はC投資銀行から保証料相当の支払いを受ける 見返りに、B社が破綻した場合の損失を C投資 銀行に補填する契約を結ぶこともできる。

CDSを使って例えばGEのプロテクションを 売ることは、実質的には資金を借りてきて GE に貸出を行ったのと同じリスクを取ることに なる。これは、GEが健全な場合には、貸出利 鞘に相当する保証料が受け取れる半面、GEが 万一破綻した場合には、貸倒損失に相当する 保証金の支払いが必要になるからである。CDS のプロテクションの販売を行うことにより、金 融機関は、全く取引のない企業に対して、自ら 貸し出しを行ったのと同じ状況を作れる。例え ば、 GEについての 5 年物の CDSのプロテクショ ンを売ることで、 5 年物の固定金利で資金調達 して、5年間固定金利の貸出しを GEに行った のと同じ状態にできる。このように、CDSは 非常に使い勝手のよい金融派生商品であり、取 引が急速に拡大してきた。

以上を言い換えると、CDSは、B社に関する いわば生命保険契約である。この契約者は、B 社が破綻すれば保険金を受け取れる。普通の生 命保険契約は、本人の了解なしでは締結できな いが、CDSの場合には何の規制もなく、誰でも、 また、どの会社に対してでも、CDSプロテク ションの売り手や買い手になることができる。

AIGはCDSのプロテクションを大量に売却 していた。特に、高格付の不動産流動化証券
の支払いを保証するCDSを大量に売却してい たと報じられている。AIGはこの保証料収入に よって、AIG全体の利益を 2 割弱、押し上げて いた。リーマンの破綻とほぼ時を同じくして、 AIGが締結していたCDSの含み損が拡大し た。この損失拡大に伴い、当初、ダブル $\mathrm{A}$ 格 のAIGは、シングル Aへの格下げに直面した。 AIGが締結していたCDS取引では、AIGの格 付が低下した場合には、AIGが将来補填しなけ ればならないCDSの含み損をカバーできる担 保を、 $\mathrm{AIG}$ の取引の相手方に差し入れる条項が 入っていた。このため、AIGは突如として巨額 の担保を置く必要が生じた。リーマンが破綻し た2008年 9 月 15 日に、AIGは資金繰りに窮し、 連銀に対して巨額の借り入れを申し込んだ。当 初は連銀も財務省も支援に難色を示していた。 しかしAIGの破綻は、AIGに対してCDS取引 の含み益を保有していた取引先に損失を発生 させ、連鎖破綻を発生させる懸念が大きかった。 結局政府は、約 8 兆 5 千億円の貸出枠を設定し、 その後も支援を追加し、合計約 15 兆円もの支 援を行う結果となった。この結果、CDS取引 によってAIGから債務保証を受けていた取引 の相手方が経営悪化する、いわゆるカウンター・ パーティ・リスク（金融派生商品などの取引相 手についての信用リスク）が注目されることに なった。

貸出に伴う信用リスクに比較すると、カウン ター・パーティ・リスクはほとんど開示されて おらず、 $\mathrm{AIG}$ の場合も、連邦議会による追及が 
行われる数ヶ月後までは、政府による AIGの 保護が、結局どの金融機関の破綻を避けるため の措置なのかが見えなかった経緯がある。この ため、世界の金融市場において、多額のCDS 取引を行っている金融機関や企業の抱えるリ スクに対する不安感が強まり、金融取引を萎縮 させた。

CDSの想定元本残高（CDSによる債務保証 の元本に相当する金額）は極めて急速に拡大し てきており、2007年末のピークには 62 兆ドル に達した。その後サブプライム問題の深刻化や ベアー・スターンズの実質的な経営破綻に伴い、 CDS取引の縮小が進み、2008年6月末では 54 兆ドルへと減少した（図表3）。しかし54兆ド ルでも、2007年における全世界の GDPに匹敵 する元本額であり、なお巨額である。以下では、 CDS取引拡大による問題点を概観してみる。

第一に、CDSのプロテクションの売り手が 抱えるリスクは、従来金融派生商品取引の中心 であった金利スワップよりも非常に大きいこ
とである。例えば単純な金利スワップの場合に は、満期が比較的長い 5 年ものの取引でも、普 通は想定元本に対して $5 \%$ から $10 \%$ 程度の損失 である。しかし CDSは実質的な信用保証のた め、最大で想定元本の $100 \%$ の損失が出る可能 性があった。

第二に、CDS取引に伴う含み損益は、想定 元本に比較して巨額になりやすいが、たとえ CDS取引で「勝ち」があっても、保証を購入 した先の金融機関が破綻すると「勝ち」が消え てしまうことである。先に述べたように、この リスクが巨額であったことが、米国政府と連銀 がAIGの破綻を回避するために資金協力した 背景にある。

第三に、担保差し入れ条項のリスクが重要で ある。例えば、原資産を持っている銀行 A が 投資銀行 $\mathrm{B}$ とのCDS取引で貸し倒れリスクを ヘッジする場合を考えてみよう。この取引相 手の投資銀行 $\mathrm{B}$ がほかの投資銀行 Cでもう一回 ヘッジして、さらに、それがもう一回ヘッジさ

図表4 CDSの相対取引連鎖と担保負担

\begin{tabular}{l}
\hline A 銀行 : 保証の \\
買い手
\end{tabular}

D保険 : 保証の 売り手
担保

\section{B 投資銀行：保証の 仲介業者}

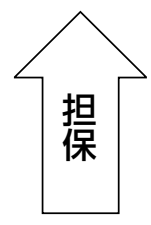

C 投資銀行 : 保証の

仲介業者 
れ、 $\mathrm{D}$ 保険会社が最終的な保証人になるといっ た形でブローカーが間に何回も入ってくる。

CDSの含み損が拡大する場合には、図表4の 取引の各段階全てで担保が必要である。このた め原資産に対して数倍の担保が必要になる可 能性がある。

第四に、CDSの保証の売りによる架空利益 計上の問題もある。本来、金融派生商品は「勝 ち」と「負け」を足したらゼロになるはずで ある。CDS取引による保証料も将来の損失の 期待值に見合っているので、本来は、ほぼ全 額を引き当てておく必要がある。しかし実際に は、AIGが多額の利益を計上していた。AIGに サブプライム関連証券などの損失をヘッジす るCDS取引を行っていた取引先も利益を計上 していたはずである。金融派生商品取引は本来 ゼロサムのため、保証を買っている側から見れ ば、保証料は将来の貸し倒れ損失のリスクに見 合っている。このため、保証料を支払っても別 に損しているとは認識していない。他方、CDS の保証を売っている側も、入ってくる保証料は、 将来の貸し倒れリスクに対応するものである ため、収入はその大半を引当処理すべきもので ある。しかしAIGはそれをやっていなかった。 このために、CDSの帳簿上の評価が、市場全 体では利益超過になっている可能性がある。こ れは、他の金融派生商品でも同じことである。 本来、ゼロサムになるべきものが、取引の双方 が、少しだけ自らにとって甘い評価にしておく と、双方が利益を出せることになる。

\section{5. おわりに}

一金融業・金融監督の行方

本節では最後に、金融業・金融監督の行方に ついて考えてみたい。

第一に、ブッシュ政権末期に行われた、資産 査定なしの資本注入には大きな問題があった。 また、リーマンの資産が元本の僅か $9 \%$ にまで なぜ悪化したのかについては、いまだに解明さ れていない。この原因究明が行われなければ、 金融機関相互の不信感もなかなか払拭できな いと思われる。

第二に、CDSなどの金融派生商品評価の透 明化とカウンター・パーティ・リスクの削減が 急務である。どこにどのくらい隠れ損失がある のか見えないため、金融派生商品の現在価值額 合計に対する世界規模の調査が必要である。

第三に、金融機関に対する自己資本規制の全 面的な見直しも必要である。特に、現在のバ リュー・アット・リスクによる資本の計算には 大きな欠陥がある。バリュー・アット・リスク の計算は、数年程度の比較的短期間のデータか ら統計モデルにより、損失のリスクを計算して 必要自己資本を推定するが、株価、為替相場な どの経済変数の動きは正規分布など普通想定 される分布よりも、例外的に大きな変動をする 場合が多い。むしろ、過去数十年程度の長期間 における最大損失を基礎とした資本規制にす べきだと考えられる。 